\title{
First record of the predatory snail Acanthinucella spirata (Blainville, 1832) north of its known range
}

\author{
Torre E. Flagor ${ }^{1}$ and Paul E. Bourdeau ${ }^{1,2^{*}}$
}

\begin{abstract}
Background: Rapidly changing marine environments have increased the need to document the expansion of organismal ranges into new, previously undocumented regions. Such range expansions can shed light on the ecological factors that promote successful spread and establishment of species in new areas, and the evolutionary processes that may lead to adaptations. Acanthinucella spirata (Blainville, 1832) is a muricid gastropod that has expanded its range northward along the California coast since the Pleistocene. Its previously documented range was from Tomales Bay, California $\left(38.2^{\circ} \mathrm{N}\right)$, to Punta Baja, Baja California $\left(22.9^{\circ} \mathrm{N}\right)$. Here we report the first record of A. spirata north of its previously defined range, along the Californian coast of North America.

Methods: Populations of reproducing muricid gastropods were found during a survey of the high intertidal zone of a moderately wave-protected boulder field on Cape Mendocino, CA (Latitude $40.396^{\circ} \mathrm{N}$ Longitude $-124.378^{\circ} \mathrm{W}$ ) on 17 June 2017. A sample of 65 individual snails were haphazardly collected and digitally photographed, weighed, and measured. Photos and morphological data were used to key individuals to species, and we used shell shape to compare collected snails to suspected Acanthinucella species and with potential source populations.
\end{abstract}

Results: Snails were positively identified as A. spirata, roughly $431 \mathrm{~km}$ north of this species' previously defined northern range limit. Snails had a mean shell length of $28.32 \mathrm{~mm}$ ( \pm 3.0 s.d.) and a mean mass of $4.23 \mathrm{~g}( \pm 1.1$ s.d.).

Discussion: Due to A. spirata's non-planktonic larval stage, hitchhiking on avian hosts or rafting are the likely causes for the northward non-contiguous dispersal of the species, especially because populations have not been reported between new and previously defined range boundaries. Such stratified range expansions, which occur via a combination of both contiguous and non-contiguous dispersal, are consistent with several recent studies documenting present-day range expansions.

Keywords: Angular Unicorn, Gastropod, Northern California, Range expansion, Stratified dispersal

\section{Background}

Over the last century, human activities, such as fossil fuel combustion and greenhouse gas emissions have led to accelerating global climate change, including atmospheric and oceanic warming (IPCC 2014). These human-induced changes to global climates have led to poleward range expansions in numerous organisms (Parmesan and Yohe 2003; Hickling et al. 2006; Parmesan 2006; Chen et al. 2011). Although modern range shifts have been

\footnotetext{
* Correspondence: peb112@humboldt.edu

${ }^{1}$ Department of Biological Sciences, Humboldt State University, Arcata, California, USA

${ }^{2}$ Telonicher Marine Laboratory, Humboldt State University, Trinidad, California, USA
}

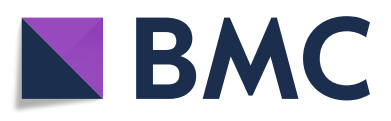

(c) The Author(s). 2018 Open Access This article is distributed under the terms of the Creative Commons Attribution 4.0 International License (http://creativecommons.org/licenses/by/4.0/), which permits unrestricted use, distribution, and reproduction in any medium, provided you give appropriate credit to the original author(s) and the source, provide a link to the Creative Commons license, and indicate if changes were made. The Creative Commons Public Domain Dedication waiver (http://creativecommons.org/publicdomain/zero/1.0/) applies to the data made available in this article, unless otherwise stated. documented in marine systems (e.g. Perry et al. 2005; Ling et al. 2009; Johnson et al. 2011; Yamano et al. 2011), they have traditionally received less study than terrestrial systems (but see Sorte et al. 2010; Wernberg et al. 2011; Sunday et al. 2012; for recent reviews of modern marine range expansions).

Both anthropogenically-mediated and natural range expansions share similar processes and dynamics that bring species into contact with new habitats, new ecological communities, and novel selective pressures (Roy et al. 2002; Sorte et al. 2010). As expanding species encounter novel environments, present-day range expansions can provide insight into the ecological factors 
that promote successful establishment in new locations, and the evolutionary processes that may lead to adaptations (van Kleunen et al. 2010; Westley 2011). For example, range expansions can occur through contiguous dispersal where a population expands into adjacent habitats over short distances, or by noncontiguous dispersal, where a population expands into non-adjacent habitats over long distances (Shigesada et al. 1995; Berthouly-Salazar et al. 2013). The latter is usually accomplished via rare long-distance natural dispersal events, or facilitated by anthropogenic activities. Recent studies have indicated that range expansions often occur by a combination of both mechanisms; so-called 'stratified dispersal' (Darling and Folino-Rorem 2009; Bronnenhuber et al. 2011). These dispersal mechanisms are known to affect genetic structure between established populations, while also producing distinctive patterns of genetic differentiation during range expansion (Shigesada et al. 1995; Ramakrishnan et al. 2010).

Whereas dispersal is necessary for range expansion, so too is the ability to respond to novel environments encountered at the range edge. Expansion into new environments exposes range-expanding species to a suite of novel abiotic and biotic selective pressures (Sakai et al. 2001). Consequently, there is a need to document present-day range expansions, while integrating information about expansion history, dispersal ability, and novel environments to better understand the factors influencing range expansions (e.g., Pfeiffer-Herbert et al. 2007) and better predict potential future range expansions of marine species (Connolly and Baird 2010).

Acanthinucella spirata is a north American intertidal carnivorous gastropod in the family Muricidae (see Keen 1971; Abbott 1974; Wu 1985). The species has expanded its distribution along the California coast since the Pleistocene, via a poleward geographical range shift in response to climatic change (Hellberg et al. 2001). The previously documented distribution of $A$. spirata ranged from Punta Baja, Baja California, Mexico $\left(22.92^{\circ} \mathrm{N}\right)$ to Tomales Bay, California, USA $\left(38.17^{\circ} \mathrm{N}\right.$; Allen and Battagliotti 1976; McLean 1978; Gianniny and Geary 1992). Juvenile $A$. spirata emerge from benthic egg capsules directly, rather than undergoing a planktonic larval stage; so, their dispersal ability is limited. Previous work documenting differences in shell morphology between Pleistocene and Recent populations of A. spirata, suggests a climatically driven late Pleistocene recolonization of the northern part of the species' range from a southern refugium (Hellberg et al. 2001). However, the population documented here was found at $40.40^{\circ} \mathrm{N}$ latitude (Fig. 1), indicating a 'jump' range expansion and the first record of this species north of its currently recognized northern geographic range limit.

\section{Methods/ materials}

Acanthinucella spirata individuals were discovered during a survey of the rocky intertidal zone of Cape Mendocino, CA (Latitude $40.396^{\circ} \mathrm{N}$ Longitude $-124.378^{\circ} \mathrm{W}$ ) on 17 June 2017. Individuals were found aggregating at a tidal height of $0.94 \mathrm{~m}$ above MLLW (measurements of intertidal heights were obtained with a laser level, using a reference point obtained by observing still tidal height on multiple days) on cobble and boulders sheltered from direct sun exposure, huddled next to egg masses (Fig. 2). After finding the initial aggregation, we noticed several more aggregations nearby and so placed a $42 \mathrm{~m}$ transect tape parallel to the shore at a tidal height of $0.95 \mathrm{~m}$ above MLLW and counted all snails within $1 \mathrm{~m}$ of either side of the tape. We then collected a sample of 65 individuals from the surveyed population and returned them to Humboldt State University's Telonicher Marine Lab (TML) for photographic and morphometric analyses. Live individuals were measured for shell length and width, total wet mass, apertural lip thickness, and aperture length and width. We used digital photos and morphological data, along with taxonomic keys (Light 2007), to confirm our initial species-level identification. We also compared the sizes and shell shapes (shell aspect ratio [shell length: shell width]) of our sampled population to those of Acanthinucella species collected from potential southern source populations (Gianniny and Geary 1992). Sampled snails were placed in holding tanks at TML to monitor feeding, growth, and reproduction. Egg capsules were removed and transferred to quarantine aquaria to monitor hatching. Seawater in the aquarium was chilled to $13{ }^{\circ} \mathrm{C}$, which is well within the natural range of seawater temperatures experienced by intertidal organisms at the collection site during summer (Bourdeau, unpublished data).

\section{Results}

Systematics.

Class GASTROPODA Cuvier, 1795.

Subclass CAENOGASTROPODA Cox, 1960.

Order NEOGASTROPODA Wenz, 1938.

Superfamily MURICOIDEA Rafinesque, 1815.

Family MURICIDAE Rafinesque, 1815.

Subfamily OCENEBRINAE Cossmann, 1903.

Genus Acanthinucella Cooke, 1918.

Acanthinucella spirata Blainville, 1832.

Individual snails that were collected at lat. $40.40^{\circ} \mathrm{N}$ possessed labral teeth, open siphonal canals, and a prominent keel at the shell shoulder, consistent with the A. spirata description in the taxonomic key (Light 2007). Shell coloration was composed of light brown ridges followed by darker valleys (Fig. 3), which was also consistent with the description in the taxonomic key. The habitat occupied by snails in our survey included the 


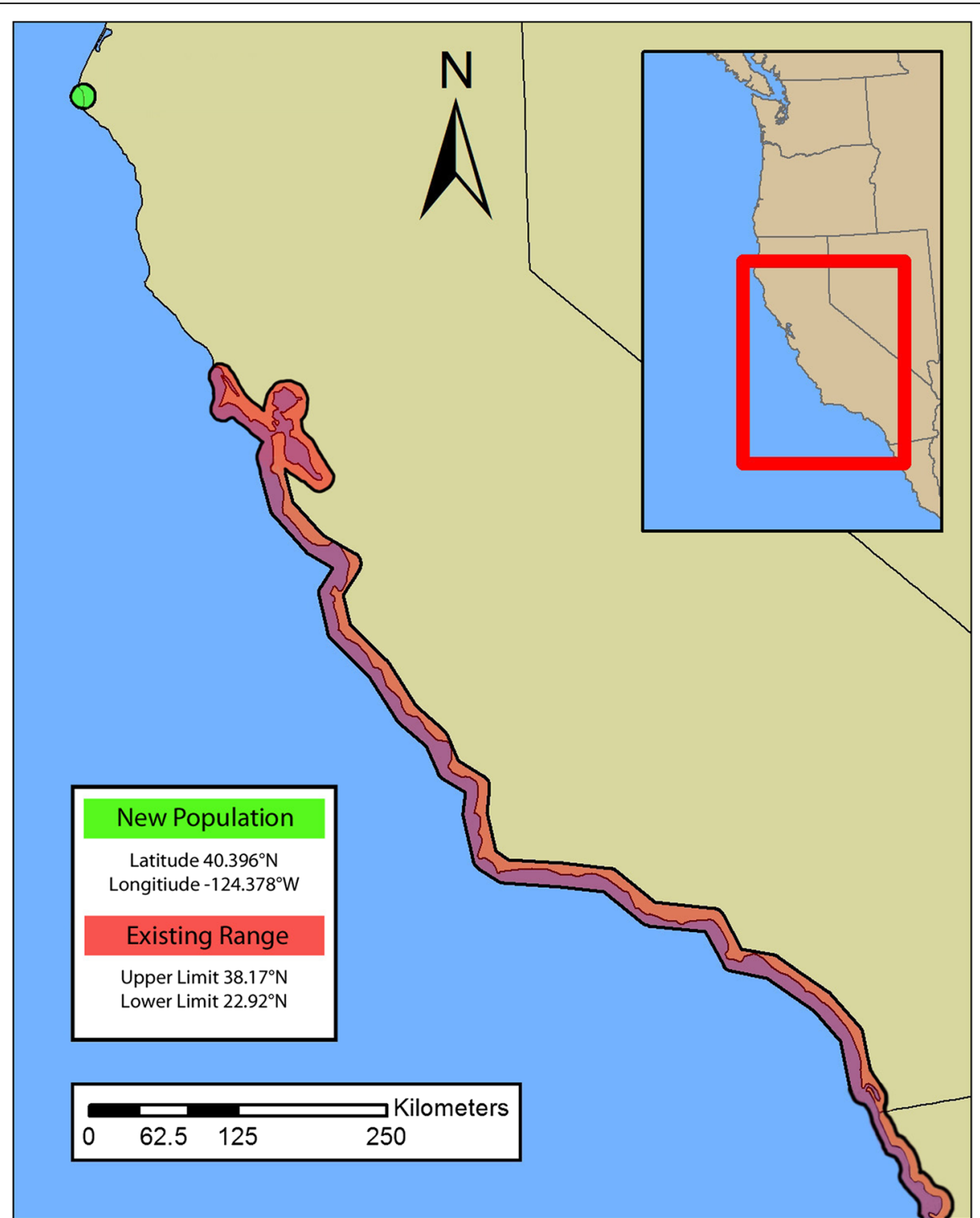

Fig. 1 Current distribution of Acanthinucella spirata. Red highlighted coastline depicts existing range. Green highlighted point depicts the newly documented reproducing population

high intertidal zone, which was composed mainly of barnacle-encrusted cobble and boulders, with a dominant algal cover composed of branching red macroalgal (Mastocarpus spp.). Estimated snail density along our transect was 0.54 snails $\mathrm{m}^{-2}$, and snails from our collection sample ranged from $21.32-33.68 \mathrm{~mm}$ in total shell length, with a mean ( \pm s.d.) of $28.31 \pm 3.0 \mathrm{~mm}$, and mean total weight of $4.23 \pm 1.1 \mathrm{~g}$. Mean shell aspect ratio was $1.65 \pm 0.1$, which was more similar to southern populations of $A$. spirata than either closely-related congeners A. punctulata or A. puncilitrata (Fig. 4). During captivity in the lab, individual snails readily consumed small barnacles (Chthamalus dalli) and produced egg capsules, however the egg capsules were not viable.

\section{Discussion}

Acanthinucella spirata has not been previously documented north of Tomales Bay, CA (latitude $38.17^{\circ} \mathrm{N}$ ). However, the population we observed during our survey was of considerable density and was actively reproducing, indicating that latitude $40.40^{\circ} \mathrm{N}$, along the northern California coast, is this species new northern boundary.

Effective dispersal is necessary for colonizing new habitat beyond a species current range. For A. spirata, a species with intracapsular development, with crawl-away young (Spight 1976), viable options for long-distance dispersal along the California coast are limited (Gibson et al. 2006). However, the absence of documented pocket populations between the new population we document 


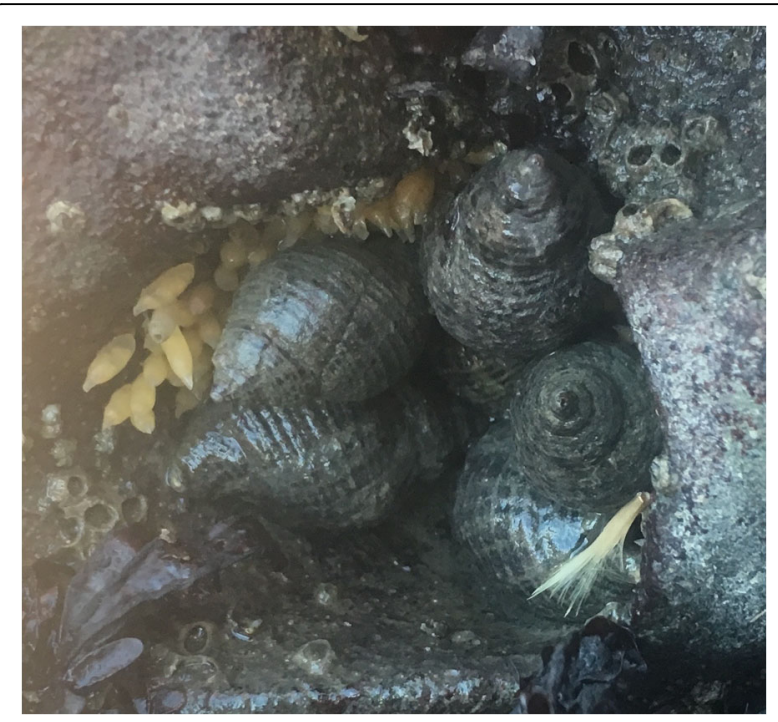

Fig. 2 Acanthinucella spirata individuals huddled next to egg capsules at latitude $40.40^{\circ} \mathrm{N}$

here $\left(40.40^{\circ} \mathrm{N}\right)$ and the previously established northern range limit $\left(38.17^{\circ} \mathrm{N}\right)$ indicates noncontiguous dispersal or a 'jump' range expansion. Given the remote location of Cape Mendocino, this was likely due to a rare long-distance natural dispersal event, rather than mediated by anthropogenic vectors. We hypothesize

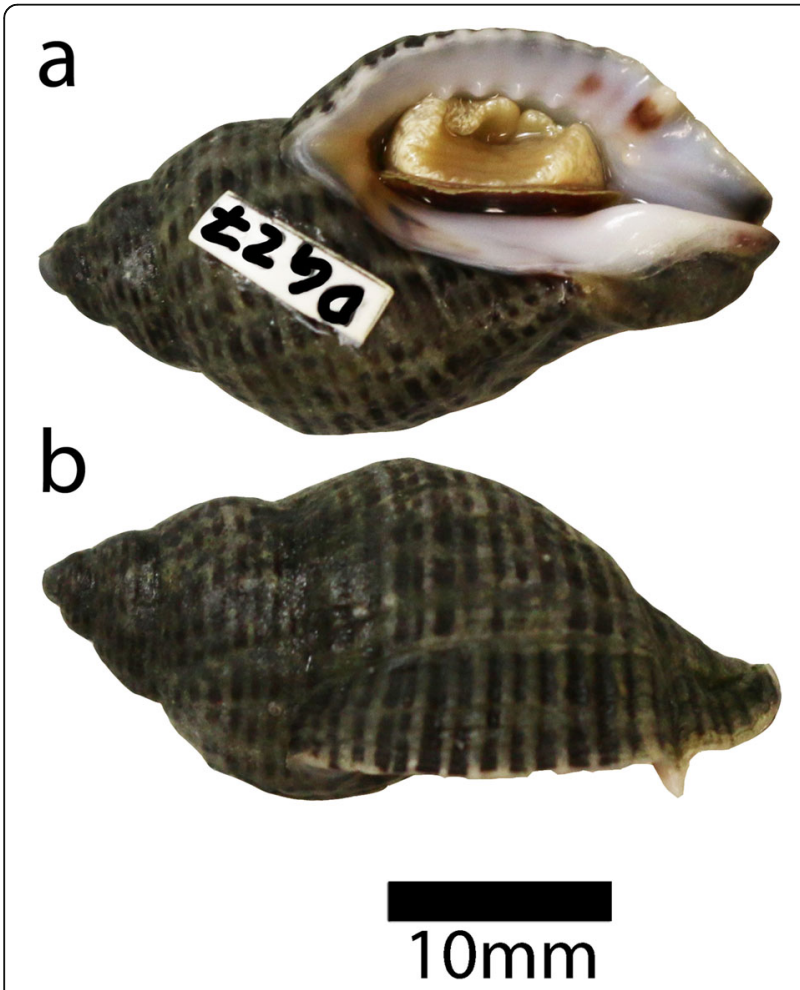

Fig. 3 a Apertural view and (b) profile view of Acanthinucella spirata collected at latitude $40.40^{\circ} \mathrm{N}$

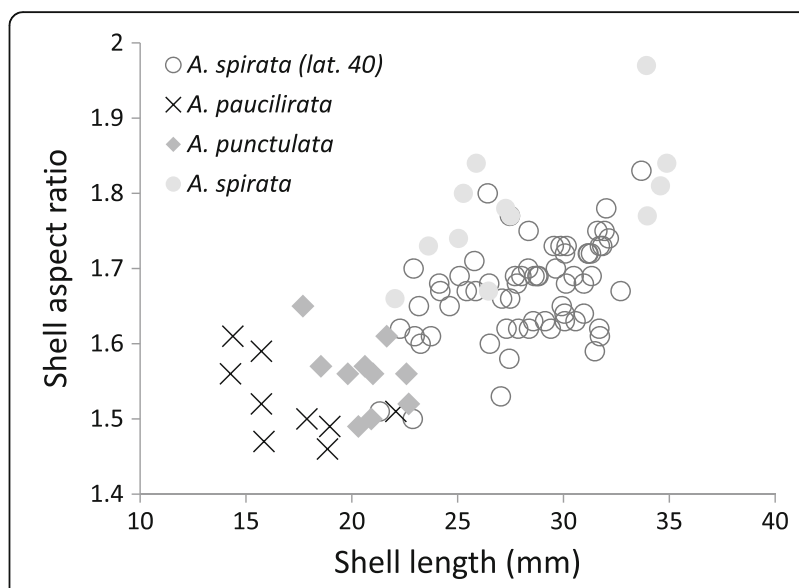

Fig. 4 Relationship between shell length $(\mathrm{mm})$ and shell aspect ratio (shell length: shell width) of southern Acanthinucella spp. individuals and northern (N latitude 40) A. spirata individuals. Southern Acanthinucella spp. individuals analyzed by Gianniny and Geary (1992)

long-distance avian-mediated dispersal (Green and Figuerola 2005) or rafting on organic or inorganic material (Thiel and Gutow 2005) as the dispersal mechanism for the present A. spirata range expansion. Our finding of noncontiguous northward dispersal, coupled with the climate-driven poleward range expansion over geological time suggest that A. spira$t a$ 's poleward range expansion might have been a combination of both contiguous and non-contigous dispersal, a mechanism for range expansion that has been documented in other species in several recent studies (Shigesada et al. 1995; Shigesada and Kawasaki 2002; Berthouly-Salazar et al. 2013).

The introduction of a novel species to a new geographic location generally has negative effects on native species (Ricciardi 1998; Cullingham et al. 2011) and $A$. spirata's range expansion into the northern California coast could pose a novel threat to the ecology of native intertidal communities. In its previously-documented range, $A$. spirata is distributed throughout the mid- and high-intertidal zones on rocky shores. As a generalist predator, it feeds naturally on two intertidal foundation species (barnacles, Balanus glandula and mussels, Mytilus californianus); a common herbivore (the black turban snail, Tegula funebralis); and sporadically on other taxa (Murdoch 1969; Ferrier et al. 2016); however, it prefers barnacles over mussels and turban snails (Zimmer et al. 2016). B. glandula and another barnacle species, Chthamalus dalli, are found locally on Cape Mendocino, and because $A$. spirata can modify competitive hierarchies, and determine population dynamics and species composition among barnacle assemblages (Lively et al. 1993; Ferrier et al. 2016), it could have significant impacts on community structure in its new location. 
Further, because barnacles are a shared resource among native muricid snails, Nucella lamellosa (Gmelin, 1791), Nucella ostrina (Gould, 1852), and Ceratostoma foliatum (Gmelin, 1791), on Cape Mendocino, the presence of high-density, reproducing populations of $A$. spirata could cause a shift in native predatory snail assemblages via reductions in barnacle populations, altering local community structure. Monitoring the integration of $A$. spirata into the rocky shore communities at the northern edge of its distribution could therefore provide valuable insight into the community dynamic shifts associated with species introductions and range expansions.

Non-contiguous dispersal, like that documented here, is known to produce characteristic patterns of genetic variation during range expansion (Shigesada et al. 1995; Ramakrishnan et al. 2010) and may profoundly affect evolutionary change, by providing new environmental contexts that can create novel ecological interactions, select for new morphologies, and even lead to speciation (Parmesan 2006; Ruiz et al. 1997; Strayer et al. 2006). Populations with relatively high levels of standing genetic variation should be better at resisting founder effects and adapt to new environments (Lee 2002; Bock et al. 2015; Schlaepfer et al. 2005). However, genetic bottlenecks and genetic drift in small founding populations will act to reduce a population's genetic diversity and adaptive potential (Klopfstein et al. 2005; Peacock et al. 2009). In its previously documented range, northern populations (between $34.5^{\circ}$ and $40^{\circ} \mathrm{N}$ latitude) of A. spirata show reduced genetic diversity relative to southern populations, a pattern consistent with a recent northward range expansion (Hellberg et al. 2001). Future studies should examine patterns of genetic variation in founding populations of A. spirata on Cape Mendocino to determine their potential to adapt to their new northern range limit.

\section{Acknowledgements \\ We thank the director and staff of the Humboldt State University Telonicher Marine Laboratory for logistical support. We thank T. McClure for making the map used in Fig. 1. Organisms were collected by the authors under scientific collecting permit \# SCP 10571 to PEB from the California Department of Fish and Wildlife. Carlo Nike Bianchi and 2 anonymous reviewers provided constructive criticism on earlier versions of this manuscript. This is a contribution of the Humboldt State University Telonicher Marine Laboratory and the Humboldt Marine and Coastal Sciences Institute.}

\section{Funding}

PEB acknowledges support from The California State University Council on Ocean Affairs, Science \& Technology (CSU- COAST) Grant Development Program.

\section{Availability of data and materials}

All data generated or analyzed during this study are included in this published article [and its supplementary information files].

\section{Authors' contributions}

TEF initiated the study and collected and analyzed the data. TEF and PEB identified the specimens. TEF photographed the specimens. TEF wrote the original draft of the manuscript, which PEB reviewed and critically revised. Both authors read and approved the final manuscript.

\section{Ethics approval and consent to participate}

This work conforms to the legal requirements of the county in which it was carried out and to accepted international ethical standards, including those relating to conservation and animal welfare.

\section{Consent for publication}

Not applicable.

\section{Competing interests}

The authors declare that they have no competing interests.

\section{Publisher's Note}

Springer Nature remains neutral with regard to jurisdictional claims in published maps and institutional affiliations.

Received: 25 May 2018 Accepted: 30 August 2018

Published online: 12 September 2018

\section{References}

Abbott R. American seashells; the marine Molluska of the Atlantic and Pacific coasts of North America. New York: Van Nostrand Reinhold; 1974.

Allen RK, Battagliotti J. Common intertidal invertebrates of southern California. Palo Alto: Peek Publications; 1976.

Berthouly-Salazar C, Hui C, Blackburn TM, Gaboriaud C, Rensburg BJ, Vuuren BJ, et al. Long-distance dispersal maximizes evolutionary potential during rapid geographic range expansion. Mol Ecol. 2013;22:5793-804.

Bock DG, Caseys C, Cousens RD, Hahn MA, Heredia SM, Hübner S, et al. What we still don't know about invasion genetics. Mol Ecol. 2015;24:2277-97.

Bronnenhuber JE, Dufour BA, Higgs DM, Heath DD. Dispersal strategies, secondary range expansion and invasion genetics of the nonindigenous round goby, Neogobius melanostomus, in Great Lakes tributaries. Mol Ecol. 2011;20:1845-59.

Chen IC, Hill JK, Ohlemüller R, Roy DB, Thomas CD. Rapid range shifts of species associated with high levels of climate warming. Science. 2011;333:1024-6.

Connolly SR, Baird AH. Estimating dispersal potential for marine larvae: dynamic models applied to scleractinian corals. Ecology. 2010;91:3572-83.

Cullingham Cl, Cooke JE, Dang S, Davis CS, Cook BJ, Coltman DW. Mountain pine beetle host-range expansion threatens the boreal forest. Mol Ecol. 2011;20: 2157-71.

Darling JA, Folino-Rorem NC. Genetic analysis across different spatial scales reveals multiple dispersal mechanisms for the invasive hydrozoan Cordylophora in the Great Lakes. Mol Ecol. 2009;18:4827-40.

Ferrier GA, Zimmer CA, Zimmer RK. Chemical ecology of wave-swept shores: the primacy of contact cues in predation by whelks. Biol Bull. 2016;231:207-15.

Gianniny GL, Geary DH. Geographic and temporal variation in shell morphology of Acanthina species from California and northern Baja California. The Veliger. 1992;35:195-204.

Gibson RN, Atkinson RJA, Gordon JDM. The ecology of rafting in the marine environment. III. Biogeographical and evolutionary consequences. Oceanogr Mar Biol Annu Rev. 2006:44:323-429.

Green AJ, Figuerola J. Recent advances in the study of long-distance dispersal of aquatic invertebrates via birds. Divers Distrib. 2005;11:149-56.

Hellberg ME, Balch DP, Kaustuv R. Climate-driven range expansion and morphological evolution in a marine gastropod. Science. 2001;29:1707-10.

Hickling R, Roy DB, Hill JK, Fox R, Thomas CD. The distributions of a wide range of taxonomic groups are expanding polewards. Glob Chang Biol. 2006;12: $450-5$.

IPCC: Climate Change 2014. In: Core Writing Team, Pachauri RK, Meyer LA, editors. Synthesis Report. Contribution of Working Groups I, II and III to the Fifth Assessment Report of the Intergovernmental Panel on Climate Change. Geneva: IPCC; 2014.

Johnson CR, Banks SC, Barrett NS, Cazassus F, Dunstan PK, Edgar GJ, et al. Climate change cascades: shifts in oceanography, species' ranges and subtidal marine community dynamics in eastern Tasmania. J Exp Mar Biol Ecol. 2011; 400:17-32.

Keen AM. Sea shells of tropical West America. Marine mollusks from Baja California to Peru. Redwood City: Stanford University Press; 1971.

Klopfstein S, Currat M, Excoffier L. The fate of mutations surfing on the wave of a range expansion. Mol Biol Evol. 2005;23:482-90.

Lee CE. Evolutionary genetics of invasive species. Trends Ecol Evol. 2002;17: 386-91. 
Light SF. The Light and Smith manual: intertidal invertebrates from Central California to Oregon. Oakland: Univ of California Press; 2007.

Ling SD, Johnson CR, Ridgway K, Hobday AJ, Haddon M. Climate-driven range extension of a sea urchin: inferring future trends by analysis of recent population dynamics. Glob Chang Biol. 2009;15:719-31.

Lively CM, Raimondi PT, Delph LF. Intertidal community structure: space-time interactions in the northern gulf of California. Ecology. 1993;74:162-73.

McLean J. Marine shells of southern California. Sci Ser Nat Hist Mus Los Ang Cnty. 1978:24:1-104

Murdoch WW. Switching in general predators: experiments on predator specificity and stability of predator populations. Ecol Monogr. 1969;39:335-54.

Parmesan C. Ecological and evolutionary responses to recent climate change. Annu Rev Ecol Evol Syst. 2006;37:637-69.

Parmesan C, Yohe G. A globally coherent fingerprint of climate change impacts across natural systems. Nature. 2003:421:37.

Peacock MM, Beard KH, O'Neill EM, Kirchoff VS, Peters MB. Strong founder effects and low genetic diversity in introduced populations of coqui frogs. Mol Ecol. 2009;18:3603-15.

Perry AL, Low PJ, Ellis JR, Reynolds JD. Climate change and distribution shifts in marine fishes. Science. 2005;308:1912-5.

Pfeiffer-Herbert AS, McManus MA, Raimondi PT, Chao Y, Chai F. (2007). Dispersal of barnacle larvae along the Central California coast: a modeling study. Limnol Oceanogr. 2007;52:1559-69.

Ramakrishnan AP, Musial T, Cruzan MB. Shifting dispersal modes at an expanding species' range margin. Mol Ecol. 2010;19:1134-46.

Ricciardi A. Global range expansion of the Asian mussel Limnoperna fortunei (Mytilidae): another fouling threat to freshwater systems. Biofouling. 1998;13: 97-106.

Roy K, Jablonski D, Valentine JW. Body size and invasion success in marine bivalves. Ecol Lett. 2002;5:163-7.

Ruiz GM, Carlton JT, Grosholz ED, Hines AH. Global invasions of marine and estuarine habitats by non-indigenous species: mechanisms, extent, and consequences. Am Zool. 1997;37:621-32.

Sakai AK, Allendorf FW, Holt JS, Lodge DM, Molofsky J, With KA, et al. The population biology of invasive species. Ann Rev of Ecol Syst. 2001;32:305-32.

Schlaepfer MA, Sherman PW, Blossey B, Runge MC. Introduced species as evolutionary traps. Ecol Lett. 2005:8:241-6.

Shigesada N, Kawasaki K. Invasion and the range expansion of species: effects of long-distance dispersal. In: Bullock J, Kenward R, Hails R, editors. Dispersal Ecology: The 42 Symposium of the British Ecological Society. Oxford: Blackwell Science; 2002. p. 350-373.

Shigesada N, Kawasaki K, Takeda Y. Modeling stratified diffusion in biological invasions. Am Nat. 1995;146:229-51.

Sorte CJ, Williams SL, Carlton JT. Marine range shifts and species introductions: comparative spread rates and community impacts. Glob Ecol Biogeogr. 2010; 19:303-16.

Spight TM. Hatching size and the distribution of nurse eggs among prosobranch embryos. Biol Bull. 1976:3:491-9.

Strayer DL, Eviner VT, Jeschke JM, Pace ML. Understanding the long-term effects of species invasions. Trends Ecol Evol. 2006;21:645-51.

Sunday JM, Bates AE, Dulvy NK. Thermal tolerance and the global redistribution of animals. Nat Clim Chang. 2012;2:686.

Thiel MA, Gutow L. The ecology of rafting in the marine environment. I The floating substrata Oceanogr Mar Biol. 2005;42:181-264.

van Kleunen M, Weber E, Fischer M. (2010). A meta-analysis of trait differences between invasive and non-invasive plant species. Ecol Lett. 2010;13:235-45.

Wernberg T, Russell BD, Thomsen MS, Gurgel CFD, Bradshaw CJ, Poloczanska ES, et al. Seaweed communities in retreat from ocean warming. Curr Biol. 2011; 21:1828-32.

Westley PA. What invasive species reveal about the rate and form of contemporary phenotypic change in nature. Am Nat. 2011:177:496-509.

Wu S. The genus Acanthina (Gastropoda: Muricacea) in West America. Special Publication of the Mukaishima Marine Biological Station. 1985:45-66.

Yamano H, Sugihara K, Nomura K. Rapid poleward range expansion of tropical reef corals in response to rising sea surface temperatures. Geophys Res Lett. 2011;38:L04601

Zimmer RK, Ferrier GA, Kim SJ, Kaddis CS, Zimmer CA, Loo JA. A multifunctional chemical cue drives opposing demographic processes and structures ecological communities. Ecology. 2016;97:2232-9.

\section{Ready to submit your research? Choose BMC and benefit from:}

- fast, convenient online submission

- thorough peer review by experienced researchers in your field

- rapid publication on acceptance

- support for research data, including large and complex data types

- gold Open Access which fosters wider collaboration and increased citations

- maximum visibility for your research: over $100 \mathrm{M}$ website views per year

At BMC, research is always in progress.

Learn more biomedcentral.com/submissions 